\title{
EUROPEAN POLICY TOWARDS REGIONAL INNOVATION STRATEGY ILLUSTRATEDWITH THE EXAMPLE OF THE MAZOVIA (POLAND)
}

\author{
BRONISŁAW SiTEK ${ }^{1}$
}

\author{
Alcide De Gasperi University of Euroregional Economy (Poland)
}

\begin{abstract}
Globalization process has a gradually stronger influence on economic development. In this new reality the main indicator is innovation. Various regions of European Union formulate Regional Innovation Strategies (RIS). The goal of this document is to formulate essential elements of regional development strategy. This kind of strategy was created for the Mazovia region. In the document we can read that Mazovia is the most innovative region in Poland, however, it is still far behind regions in highly developed countries. The main strength of Mazovia is the fact that it is a capital region, which means a better access for enterprises to information, important contacts and promotion. Nevertheless, we still can experience many barriers, undermining regular regional development, such as insufficient grants for scientific research or inadequate engagement of public administration to help entrepreneurs.

KEYWORDS: innovation, strategy of development, business environment institutions, friendly administration, region.
\end{abstract}

JEL CODE: R110

\section{Introduction}

Contemporary globalization processes have a growing influence on governments of particular countries, but also on decisions of local and regional authorities. One of the signs of globalization is the weakening role of state, and its position, with simultaneously growing autonomy of regions. Globalization doesn't bring state's sovereignty to an end but it leads to rationalization of political and social functions executed by the state. Thanks to that, regional authorities are given a bigger scope of statutory and actual competences, as well as bigger responsibility for local matters. Among them, it is important to list a need for economic, scientific and social development (Wojtaszczyk, Jakubowski, 2007: 254).

Despite efforts having been made, we can still observe big differences in the level of economic development among particular states and regions in Europe. In the framework of emerging regional policy of the European Union, there are actions being taken, which are aiming to implement the policy of cohesion, which goal is to avoid existing disparities. With regards to the policy, many initiatives are taken, such as bringing financial programs to life, creating new institutions, including Committee of the Regions. However, the biggest step forward was to remove barriers that inhibited free flow of people, services and capital (ZabalaIturiagagoita, Jimenes-Saez, Castro-Martinez, 2004: 1145).

One of the most important factors of regional development is its connection with science, especially innovation- a crucial element driving enterprises to develop. Innovation allows us to perceive new possibilities of development and find new forms of creativity, accumulate know-how and bring organization of work to a higher level (Schumpeter, 1986: 894). Another important element of innovation is applying new

Bronisław Sitek - Alcide De Gasperi University of Euroregional Economy, Prof. dr. habil. Scientific interest: Roman law, comparative law, European law.

E-mail: bronislaw.sitek@gmail.com,

Tel. +48227896096. 
procedures of production or human resource management http://www.come.uw.edu.pl/stypendia/files/Mazowieckie_RSI.pdf [2012-03-19].

The subject of this elaboration is to analyze regional innovation strategies, recommended by the European Union and implemented by particular regions. More than 100 regions in the EU have formulated the strategy, including 15 out of 16 regions in Poland. A thorough analysis will be given to the regional strategy of Masovian Voivodeship that was implemented by its assembly, Sejmik of Voivodeship, for the 2007-2015 period (http://www.come.uw.edu.pl/stypendia/files/Mazowieckie_RSI.pdf [2012-03-19]).

The goal of the elaboration is to evaluate the presumptions and effects of implementation of regional innovation strategies, particularly those concerning Masovian Voivodeship. It is also vital to show the value of such strategies, as many of such initiatives become just empty words that are important only of the ruling party. I will also try to indicate possible solutions that could help to better use regional innovation strategies.

The subject of the elaboration does not appear very frequently in strictly scientific publications. Nevertheless, we can find many publications and analysis of this issue that are available on the Internet. The analysis of regional innovation strategies is a very alluring and up-to-date issue as the European Commission ordered to renew them before 2014. Taking this action is necessary because of a need to rationally utilize EU financial resources by the regions (http://ris.slaskie.pl/en/articles/about_project/0/268 [2012-03-19]).

The research task of this paper is to define the concept of "regional innovation strategy", the definition of conditions creating the concept of Mazovia Regional Innovation Strategy and the definition of the innovation phenomenon in the province of Mazovia. An important task is to identify factors influencing the innovation of Mazovia, including identification of business environment and quality of business relationships with the public administration. The results of this study are achieved through the analysis of documents that are recognized as soft law. It can be assumed, therefore, that not binding nature of these documents make their efficiency very low. Hence it seems necessary to take steps to measure these effects quantitatively by referring to the results of the efficiency of already developed regional innovation strategies.

\section{What is regional innovation strategy?}

According to a common belief, the innovation system is headed towards widely understood business. Surprisingly, one of the crucial elements of this system is public administration, including the one on the regional level. This administration is not only the user of innovation created in public or private sector, but it also has big influence on the implementation process (ADIT, 2008).

The regional strategy is an element of region's strategic management. The management comprises all functions connected with formulation and implementation of regional strategies, as well as project management, financial management and control. Thus, regional strategies are one of the key elements of regional management. They are created on the level of bigger organizational units, such as lands, provinces or voivodeships in Poland. The strategies are the basis for development of regional policy on the level of self-governing voivodeship. The regional strategies should be consistent with:

- decision-making competences of voivodeship governments;

- a need to create partnership relations with national and local level of public authorities;

- a need to have partnership relations between voivodeship government and private sector together with social partners;

- requirements of the EU regarding, in particular, goals, principles and directives of structural funds (Klasik, 2000: 8).

The above-mentioned globalization process requires complete restructuring of regions. Transforming regions need to become more competitive. As a consequence, the actions of regions need to be headed towards new types of production, services, areas of education or a completely new lifestyle of an entire local community. This, in turn, requires a new management class to be emerged - a class that is able to cope with new challenges, notably with reference to creating information society. Therefore, we require transfer of technology and 
information connected with internationalization and exchange of experience. In readings as well as in EU documents there are following types of innovation listed: product innovation, process innovation, organizational innovation and marketing innovation. We can also observe an absolute innovation, when it is a completely new solution on a global scale, or it can be a new solution for a particular enterprise (but already known somewhere else) - then we can speak of imitational innovation. Another important symptom of this phenomenon is the change of people's mentality in their everyday lives, but most of all, in professional, business and consumer life.

Thus, innovation becomes a driving force for all changes, including those on a regional level. Innovation must be present in all priorities and objectives indicated by regional policies. Regions need to become spiritusmovens in the area of creating capability to action in a new way that brings more satisfactory results. Regional authorities need to motivate private enterprises in a way that they consistently search for and utilize results of scientific research as well as R\&D (research and development) (Swadźb, 2002: 15).

Regional innovation strategies (RIS) are planning documents. Their goal is to coordinate actions taken by region in a way that they lead to increase of innovation. RISs are created by the authorities of a region. This type of document was first created in the mid 90s of 20th Century. The document's role is to collect data in the planning process and is as basis for implementing objectives (Cook, 2000: 2).

The creation of RIS can be divided into a couple of steps, which are as follows:

- perform diagnosis before the planning action starts. It consists of sectorial analysis of regional economy, direct and focused interviews as well as interpretation of collected data-most frequently with use of SWOT analysis;

- formation of goals by confronting actual state of affairs, and plausible changes to it, with aspirations of the authorities, businessmen, scientific research centers and other subjects to regional innovation system;

- RIS implementation (Sztando, 2011: 521).

First steps in order to implement innovative actions in European Communities were taken in the 80s. One of those actions was the implementation of a program called STRIDE (Science and Technology for Regional Development in Europe), which priority was to intensify research and speed up technological development on a regional level. Back then, the European Commission placed emphasis on creating regional subprograms supporting the innovation. In order to strengthen strategic planning in the area of technology in particular regions, it was decided to create subprograms called Regional Technology Plans (RTP). It was expected that these programs would increase innovativeness of the regions. RTP was build based on individual approach to each of the regions. The feedback analysis of STRIDE indicated a need to take further actions. In the 90s the European Commission proposed introduction of subsequent programs, especially Regional Innovation and Technology Transfer Strategies and Infrastructures (RITTS) and Regional Innovation Strategies (RIS). RITTS program was launched in 1994 and it was supervised by DG XIII (enterprises). The goal of this project was to improve the quality of affiliation between technology-supporting subjects, financial institutions and needs of regional enterprises. In turn, RIS program has been launched by DG XVI (Regional Policy). Both programs are similar to each other. RIS program places more emphasis on building widespread partnership between important entities in the region and European Regional Development Fund. It is hoped that this program will shape a new consciousness in all areas of life, including economics. As a consequence, it should create a new culture of innovativeness, increase efforts in regional infrastructure, and strengthen potential and competences of small and middle-sized enterprises. This all should create a triangle of cooperation: business - science - (regional) administration. Regions should initiate creating new clusters and webs, as well as ensure coordination and exchange of experience between the regions (Szultka, 2004: 11-15).

\section{Conditions of Regional Innovation Strategy for Mazovia region}

Regional Innovation Strategy for Mazovia region is not a random document but it perfectly fits itself among similar strategies that have been created for other regions in the EU, starting from the beginning of 
the 90s. Creators of this strategy are aware of changes taking place in production processes, particularly the trend of resigning from mass production and choosing elastic production instead. Rapidly changing trends require quick reaction from the producers or service providers. Creators of the strategy are therefore aware that innovativeness is a paradigm of globalization. New technologies and new solutions though, shorten the distance (even the physical one) between the providers and customers.

Regional Innovation Strategy for Mazovia is a reflection of arrangements made in the Lisbon Strategy. In 2000 the European Council accepted a strategy on development of the EU for the next decade. Although, the European Union has failed to implement this strategy in practice, it is valuable to notice that the ideas, that the document contained, were reasonable and consistent with the worldwide trends of economic development. Politicians in Lisbon agreed that innovativeness should be a cornerstone of the European economy. The source of the innovativeness should be scientific research, particularly in applied sciences (Barbachowska 2011: 84). Back then, the following goals were formulated:

- Increase of expenditure for research and development to the level of $3 \%$ GDP;

- Reduction of bureaucracy and other impediments faced by entrepreneurs;

- Increase in employment to the level of $70 \%$ for men and 60\% for women (Brocka-Palacz, 2009: 20).

The policy of innovativeness, defined in the Lisbon Strategy, was supposed to become one of the basic instruments for strengthening the role of not only particular states, but also regions in their struggle against competitiveness of products from USA, China, India and other Asian countries. Implementation of the Lisbon Strategy was bound up with the implementation of structural funds and Framework Programmes.

Structural funds of the European Union are focused on the goals related to the growth of innovation and innovativeness. Therefore, all the programs that are created on both state and regional level, include actions and propositions of the projects that would increase innovativeness and innovation potential of Poland and respective regions (e.g. Operational Programme Innovative Economy, Operational Programme Human Capital, Regional Operational Program for the Masovian Voivodeship etc.) (Regionalna Strategia Innowacji dla Mazowsza, 2007-2015: 7).

In case of the Framework Programmes, it is worth emphasizing that the budget for the $6^{\text {th }}$ Framework Programme of the European Commission was the third biggest one, after agricultural policy and structural funds. In 2013 the expenditure for the $7^{\text {th }}$ Framework Programme will outnumber by $75 \%$ the funds assigned in 2006 to the $6^{\text {th }}$ Framework Programme.

Regional Innovation Strategy for Mazovia is also related to other documents having been created, directly or indirectly, as result of the Lisbon Strategy. In particular:

- "Innovation Policy in a knowledge economy" (2000);

- Subsequent reports regarding cohesion in the UE, notably "Growing regions, growing Europe. Fourth report on economic and social cohesion" (2007).

The analyzed document was created in 2006 and it is perfectly compatible with similar documents already existing in the European Union or Poland. Its creators hope that the implementation of the ideas embedded in the document would improve the present situation in the Mazovia region, especially in the area of competitiveness. It is assumed that in every bigger town in Mazovia there will be a technology park that would become a place of creating possibilities for scientific research and, most importantly, implementing the effects of this research.

RIS for Mazovia Region is a document closely associated with another strategic documents. In pt. 19 of the document the following documents were pointed at:

- "Strategy of development for the Masovian Voivodeship until 2020", which contains three goals: building the information society and improving the quality of life of Voivodeship's inhabitants; increasing competitiveness of the region on the international level; improving social, economic and spatial cohesion of the region; 
- "Strategy of e-development of Masovian Voivodeship" that focuses on information and communication technologies.

\section{Characteristic of Masovian Voivodeship}

Masovian Voivodeship is the biggest voivodeship in Poland. It has a surface of $35.559 \mathrm{sq} \mathrm{km}$ and this is more than $11 \%$ of the surface of the whole country. To better illustrate its potential, it is worth mentioning that the surface of Estonia is $45.226 \mathrm{sq} \mathrm{km}$, so it's not much bigger than the Masovian voivodeship. The population of the region is $5.170 \mathrm{mln}$. inhabitants. The population density is 145 people per sq $\mathrm{km}$, whereas Poland has a density of 112 people per sq $\mathrm{km}$. Mazovia is a highly urbanized region and the unemployment rate is one of the lowest in the country $-10.4 \%$ compared with $13.2 \%$ in the rest of the country. ${ }^{2}$

The Masovian Voivodeship is the best-developed region in Poland. According to pt. 22 of the RIS for Mazovia the value of GDP in this region, which is one of the 16 regions in Poland, is approximately $20.5 \%$ of the country's GDP. The amount of GDP per 1 person in the Masovian Voivodeship is 36.6 thousand PLN and it is more than $150 \%$ of the country's average (24.2 thousand PLN). This is one of the reasons why Masovian Voivodeshipis a leader in many rankings concerning economic potential and competitiveness of the Polish regions. It is particularly visible in all rankings regarding absorption of the competitive-innovative potential as well as innovative potential.

Mazovia, being the undisputed economic leader in Poland, including the area of implementation of innovation, is still far behind in the European rankings, especially in comparison with the regions of the so-called "old Europe". Poorer regions can be found only in the countries that joined the EU only recently- namely Bulgaria and Romania. Among 260 regions that were included in the ranking, Masovian voivodeship was placed at $213^{\text {th }}$ place. When it comes to the amount of expenditure for scientific research, it is slightly better Mazovia is on $138^{\text {th }}$ place.

According to pt. 46 of RIS Masovian Voivodeship is an attractive region for both domestic and foreign investors. Investment expenditure amounts to ca. 4000 PLN yearly per person whereas the national average is 2150 PLN. However, the expenditure is not evenly allocated and it is easy to see that sectors such as architectural engineering, public administration, defense infrastructure or business services are given insufficient grants. On the contrary, the investing expenditure in the areas such as transport, telecommunication, education and tourism (esp. accommodation sector) is constantly growing.

\section{Innovativeness in Masovian Voivodeship}

Masovian Voivodeship has one of the highest rates of investment expenditure in Poland. More than $42.5 \%$ of enterprises bear costs of investment expenditure (pt. 49 RIS). However, it's worth pointing out that the high-tech solutions appear mainly in big and middle-sized enterprises. When it comes to small and so-called micro-enterprises, the innovativeness effect is much weaker that in similar companies in other parts of Poland- in this ranking Mazovia is situated on $11^{\text {th }}$ place (pt. $50 \& 51$ of RIS). This situation is probably an outcome of the situation in the country, where small and middle-sized companies don't have funds sufficient to allocate part of their spending on innovation. Nevertheless, Mazovia has the highest index in implementing technologies form the high-tech area. New technologies are vastly used in pharmaceutical, computer and cosmetic industry (pt. 54 of RIS).

Expenditure on investment operations is incurred mainly by private enterprises and this amounts to almost $96 \%$. Money is invested in buying new machines, technological appliances and new technologies. However, it is worth pointing out that those forms of innovative purchases don't go together with acquiring the newest technologies or high-tech devices. Sellers usually dispose of appliances or technologies that had already been used in highly developed countries. Thus, we can speak of imitative innovativeness. The big-

All data is taken from the main website of the Polish Central Statistical Office: http://www.stat.gov.pl/gus/5840_1446_PLK_ HTML.htm [2012-03-21]. 
gest shortcoming is lack of cooperation between business and science (and that includes research being made in academic institution). Entrepreneurs don't see any point in investing in scientific research in order to overtake other regions or countries. Hence, the amount of expenditure in R\&D sector in Masovian Voivodeship is merely $9 \%$. In comparison, in highly developed countries this is around $40 \%$ (pt. 55 of RIS). The biggest investments were made in sectors such as food, chemical, IT and pharmaceutical industry (Pietruszyńska, 2006).

This shows that external support for SMEs (small and middle-sized enterprises) in acquiring funds for innovation in production process is a necessity. A particular role is to be played by the regional authorities, which task is not only distribution of cohesion funds, but also stimulating entrepreneurs to take innovative actions. Unfortunately, Mazovia is the region whose support for innovative enterprises is the weakest in the country.

Effects of Mazovia regional authorities' innovative actions, which are taken together with entrepreneurs, are best seen in the area of improvement of production quality and providing services. Mainly large companies, having more financial resources that could be allocated for scientific research or acquiring new technologies, have exposed those effects.

For the innovation implementation process it is important to define the sources of information. The most important thing is an external source, i.e. a possibility of acquiring data through the interested enterprise. Another, equally important sources of information about innovation are conferences, fairs and exhibitions, periodicals or scientific publications. What is worrisome is that entrepreneurs take little, or no advantage from information provided by consulting companies, universities and colleges, research institutions or Polish Academy of Sciences' units (pt. 60).

Another important factor having strong influence on increasing innovativeness in the enterprises is cooperation and diffusion. The cooperation should include not only the companies their selves, but also institutions of public administration, colleges/universities and foreign subjects. The cooperation analysis presented in Mazovia's RIS (pt. 61) shows that entrepreneurs prefer vertical agreements, i.e. agreements between clients and suppliers. Large enterprises prefer cooperation with foreign suppliers. In turn, SMEs reluctantly sign agreements with foreign partners.

Implementation of innovation faces many barriers that have various forms, depending on the size of the enterprise and its position. One of the most important barriers to innovation are (Wojnicka, 2007):

- too high costs of taking innovation in the region of Mazovia, (whereas in many regions of countries there were no resources available). Most of the enterprises finance any innovation at their own expense. Hence, support from the authorities is a necessary condition notably for SMEs, e.g. from the structural funds;

- many enterprises, especially SMEs, find it relatively difficult to find business partners;

- lack of qualified personnel;

- entrepreneurs have insufficient knowledge regarding innovation, means of implementing innovative programs in their enterprises, possibilities of gaining help from the public administration;

- Insufficient support from the authorities, particularly from the local authorities.

In comparison with the rest of the country Masovian Voivodeship is situated at the first place when it comes to the advancement in the scientific and research-development sphere. There are 332 scientific-research facilities within Mazovia region, which is $30 \%$ of all Polish facilities of this type (pt. 67). However, the total sum of expenditure in this area is unsatisfactory, since $83.7 \%$ of the costs incurred are personal costs and mere $16.3 \%$ are resources allocated on investment in fixed assets. This, in turn, causes underfunding of the scientific base, which might result in collapse of development research in predictable future (pt. 68). Another unsetting phenomenon is the fact that expenditure on research and development comes largely from the state's budget and it amounts at $60.5 \%$, and the expenditure from entrepreneurs is estimated at merely $7.3 \%$ (pt. 72). This huge disproportion of the expenditure's origin in this area results from inadequate activity of the research centers that don't establish communication with the entrepreneurs. 
Innovation possibilities of Masovian Voivodeship presented in this part of the elaboration show that it is the fastest developing region in Poland. Despite existing barriers in implementing innovation, Mazovia has the biggest potential to cooperate with another regions, including those outside of Poland.

\section{Factors having influence on innovativeness of Mazovia}

Literature points out many factors having influence on the increase in innovativeness. According to RIS, one of the most important factors concerning Mazovia is:

- business environment institutions;

- the quality of relations between business and public administration.

\subsection{Business environment institutions}

There are 43 business environment institutions in the area of Masovian Voivodeship. These include: associations for regional and local development, development agencies, guilds and chambers of commerce, specialized local government units and colleges/universities active in the R\&D area. These institutions are not evenly spread across the region. The majority of them, nearly $60 \%$, are based in Warsaw. Another $23 \%$ of them are based in towns with population bigger than 50.000 inhabitants. Therefore, there are still vast areas in the region void of influence of those institutions (Matusiak, 2007, pt. 79). Since some time, preparations have been made to create Płock Industrial and Technological Park as well as Warsaw Technological Park. However, for the time being, those units still haven't come into existence. Instead, there are various other institutions, such as: Polish Agency of Enterprise Development, Industry Development Agency, Polish Federation of Engineering Associations, Polish Chamber of Commerce, Foundation for Polish Science, Information Processing Institute, Foundation for Academic Business Incubators and many other (pt. 81) (Swianiewicz, Dziemianowicz, Mackiewicz, 2000).

The undertaken analysis (pt. 82) shows that we can list the following obstacles that impede effective work of enterprise and innovativeness support units:

- lack of financial resources that could be allocated to buy necessary equipment and to improve the standard of provided services, problems in cooperation with local and regional authorities and little (or lack of) support from their side;

- staffing issues and lack of back-up in form of scientists and consultants;

- lack of technology transfer procedures;

- presented offer mismatches the needs of the market and SMEs;

- lack of measurable benefits from the cooperation and limited commercial capability of the offered solutions;

- distrust and suspicion that is dominating in mutual contacts combined with a conviction about low qualifications of potential partners. This attitude is a straight effect of lack of experience and cooperation patterns.

\subsection{Quality of the relations between business and public administration.}

One of the cornerstones of innovativeness is friendly administration. This attitude is common in Germany, Austria and other well-developed countries. Alas, this is not the case in the countries that recently joined the European Union and one of good examples of this are Masovian Voivodeship's authorities. According to the data included in pt. 85 of RIS, public administration, including the one on the regional level, does not support the enterprises well enough in their innovative actions. The majority of communities in Mazovia is qualified as passive communities, i.e. those that are not active in the process of fundraising from the EU, and that includes the area of innovative actions. 
Obviously, EU funds are not the only ones that regions or communities should use (Dziemianowicz, 2007). Likewise, in this area, the whole region (as well as particular communities) is placed on the bottom of regions' ranking in Poland. In this area the leaders are communities from West Pomerania and Lesser Poland.

However, the innovativeness of the Masovian Voivodeship comes from the fact that it has the capital of Poland within its borders. All chief and central administration institutions of Poland based in the region stimulate the increase in innovativeness thanks to e.g. easier and quicker access to information, more possibilities of establishing contacts (both domestic and foreign), better promotion of the region and enterprises within.

\section{Conclusions}

Innovation is a basis of economic growth of states, regions, and communities but most of all, enterprises. Process of implementation of new technologies, procedures or, in other words, new thoughts, has been intensified since the $80 \mathrm{~s}$ of the previous century. This is followed by respective actions taken by the European Union, Member States and their regions. One of the most visible effects of those steps being taken is creation of Regional Innovation Strategies (RIS). Such a document can be found in most of EU's regions. The main objective of this document is to show hitherto achievements in implementing new ideas, generated by research units for production purposes or for the use of the service sector (R\&D) (European Commission, 2007).

RIS has been developed for the Masovian Voivodeship too. Having read the document that Mazovia we can conclude that is the most innovative region in Poland, however, in comparison with all the best EU regions it is two more than two hundred places behind. Thus, this is the region having the most innovative implementation processes in Poland.

However, it is important not to forget about many barriers preventing even better implementation of innovation. The most important are:

- relatively low expenditure on scientific research coming from the private sector;

- insufficient coordination of innovative actions from the regional authorities;

- enterprises, particularly small and middle-sized ones, lack support from the regional authorities;

- no system making research and development in the region compatible with the needs of the market;

- need for increasing activity of public administration and bigger engagement in helping the entrepreneurs.

It is believed that RIS is a necessary document that could give us a view over the whole voivodeship, but at the same time, we can observe too much formality of the authorities on the levels of preparation and implementation processes. Much suggests that the RIS is a good material for a brief analysis but it's not very useful when it comes to implementing it.

\section{References}

ADIT. (2008). Méthode de diagnostic du système d'innovation dans les régions françaises, Paris. Website: www.adit.fr/ IT/download/etude.php?id_titre=3 [2012-03-21].

Altshuller, G. S. (1984). Creativity as an Exact Science. The Theory of the Solution of Inventive Problems. CRC Press.

Barbachowska, B. (2011). Rola kadry kierowniczej w budowaniu potencjału kapitału intelektualnego, na podstawie przedsiębiorstwa „X” - studium przypadków. Journal of Modern Science, Vol. 4, No. 11. p. 83-94.

Brocka-Palacz, B., Teichman, E. (2009). Strategia lizbońska z perspektywy wybranych krajów i regionów. Warszawa: Szkoła Głowna Handlowa.

Cook, Ph. (2000). The Governance of Innovation in Europa. Regional Perspectives on Global Competitiveness. London: Wellington House.

Dziemianowicz, W. (2007). Wymiary pasywności lokalnej-wyniki badań ankietowych. W: W. Dziemianowicz, P. Swianiewicz (eds.). Pasywna gmina. Warszawa: Studia KPZK PAN.

European Commission. (2007). Innovative Strategies and Actions: Results of 15 Years of Experimentation. Website: http://ec.europa.eu/regional_policy/funds/2007/innovation/guide_innovation_en.pdf [2012-03-21]. 
Klasik, A. (2000). Strategia rozwoju region. Studia Regionalne i Lokalne, Vol. 3, No. 3. p. 7-22.

Matusiak, K. B. (2007). Potencjat instytucji wsparcia $w$ województwie mazowieckim. Materiał niepublikowany, opracowany w ramach projektu RIS MAZOVIA. Warszawa: Mazowiecki Urząd Marszałkowski.

Pietruszyńska, K. (2006). Promocja osiagnięć badawczych jednostek naukowych wśród przedsiębiorstw i instytucji otoczenia biznesu na przykładzie Mazowsza - podejmowane działania, potrzeby i bariery. Raport z badania. Materiał niepublikowany, opracowany w ramach projektu RIS MAZOVIA. Warszawa: Mazowiecki Urząd Marszałkowski.

Regionalna Strategia Innowacji dla Mazowsza 2007-2015. Website: http://www.come.uw.edu.pl/ stypendia/files/Mazowieckie_RSI.pdf [2012-03-21].

Schumpeter, J. A. (1986). History of Economic Analysis. London: Allen\&Unwin Ltd.

Swadźb, S. (2002). Edukacja i innowacyjność w rozwoju regionów. Tychy: Śląskie Wydawnictwa Naukowe.

Swianiewicz, P., Dziemianowicz, W., Mackiewicz, M. (2000), Sprawność instytucjonalna administracji samorzqdowej w Polsce-zróżnicowanie regionalne. Warszawa: IBnGR.

Sztando, A. (2011). Europejskie Regionalne Strategie innowacji jako źródło wzorców dla Polski. Prace Naukowe Uniwersytety Ekonomicznego we Wrocławiu, No. 152. Wrocław: Uniwersytet Ekonomiczny we Wrocławiu.

Szultka, S., Tamowicz, P., Mackiewicz, M. (2004). Regionalne strategie i systemy innowacji. Najlepsze praktyki. Rekomendacje dla Polski. Gdańsk: Instytut Badan nad Gospodarką Rynkową.

Wojnicka, E. (2007). Analiza trendów regionalnych $i$ narodowych $w$ zakresie innowacyjności, przedsiębiorczości $i$ wzrostu gospodarczego. Ekspertyza przygotowana na potrzeby projektu RIS MAZOVIA. Warszawa: Mazowiecki Urząd Marszałkowski.

Wojtaszczyk, K. A., Jakubowski, W. (2007). Spoteczeństwo i polityka. Podstawy nauk politycznych. Warszawa: Aspra-JR.

Zabala-Ituriagagoita, J. M., Jimenes-Saez, F., Castro-Martinez E. (2004). Evaluating European Regional Innovation Strategies. European Planning Studies, Vol. 16, No. 8, p. 1145-1160.

\section{EUROPOS REGIONINE INOVACIJU STRATEGIJA, ILIUSTRUOTA MOZOVIJOS (LENKIJA) PAVYZDŽIU}

\section{BRonisŁaW SiTEK}

Alcide De Gasperi euroregionu ekonomikos universitetas (Lenkija)

\section{Santrauka}

Globalizacijos procesas daro vis didesni poveiki ekonomikos vystymuisi. Šioje naujoje realybejje svarbiausiu rodikliu tampa inovacija. Ivairūs Europos Sajungos regionai kuria regionines inovacijų strategijas (RIS). Šio straipsnio tikslas - apibrèžti esminius regionų vystymosi strategijos aspektus. Tokia strategija buvo parengta Mozovijos regione, kuris yra inovatyviausias Lenkijos regionas, nors vis dar gerokai atsilieka nuo labiau išsivysčiusių šalių regionų. Pagrindinis Mozovijos regiono privalumas - jame įsikūrusi Lenkijos sostinè, tai reiškia, kad organizacijoms lengviau prieinama svarbi informacija, kontaktai ir parama. Vis dèlto šiame regione iškyla sunkumų, kurie stabdo regiono vystymąsi. Iš jų paminètini nepakankamas mokslinių tyrimų finansavimas ir nepakankama parama verslui.

PAGRINDINIAI ŽODŽIAI: inovacija, vystymosi strategija, verslo aplinkos institucijos, draugiška administracija, regionai. 